\title{
THE CONFLICT OF LAWS IN COMMERCIAL ARBITRATION*
}

\author{
David S. STERN $\dagger$
}

Almost two decades have passed since Lorenzen's treatment of this subject. ${ }^{1}$ The development of the law in this field shows that his pioneer work has been neglected. There have been many diligent laborers in the field of arbitration in general. ${ }^{2}$ Perhaps the difficulty of the fight to establish this process has forced them to devote most of their energies to establishing the more basic points in the arbitration process. Whatever the explanation, the conflict of laws has not done well, has not dealt kindly with arbitration; the myth of the ouster of jurisdiction still survives, and voices are still raised against the economic powers making "their own" law. As for the rest of the courts and writers, either a studied neglect or a calculated confusion remains. ${ }^{3}$

* 'The author wishes to express his appreciation for the invaluable assistance of Richard W. Rodgers, a member of the Florida bar, and Harold Friedman, a member of the New York bar, who are, however, in no way bound by the result; and to Edwin H. Smith, Reading Consultant, University of Miami, sincere thanks are due for running the Flesch formula on the text. It is hoped that the pleasure and enjoyment of the readers hereof will be increased as a result of his activities. No responsibility on his part, however, is assumed for the readability of the footnotes.

†B.S. 1939, LL.B. 1947, Harvard University; LI.M. 1949, New York University. Associate Professor of Law, University of Miami School of Law.

${ }^{1}$ Lorenzen, Commercial Arbitration-International and Interstate Aspects, 43 Y ALE L. J. 716 (1934), reprinted in Selected ARTICLES on the Conflict of Laws 454 (1947) [hereinafter Lorenzen, the page reference to the reprint edition]. There has been no attempt to go behind Dr. Lorenzen's truly magnificent treatment of this subject, and it is highly recommended that any reader of the present article, should he find its background deficient, refer to Lorenzen as the foundation. The conclusions stated in this article are, in all modesty, based on his conclusions, and the predisposition that the conflict of laws has neglected commercial arbitration or vice versa (see note 26 infra) is based, to a very large extent, on the failure to recognize, deal with, and attempt a solution of the problems raised at the time he was writing. The inescapable conclusion is that these problems, still unanswercd, are the core of the difficulty in this field.

${ }^{3}$ Frances Kellor, American Arbitration, Its History, Functions, and Achievements, Annex I (1948).

${ }^{3}$ The statement that this field represents a studied neglect is borne out by the fact that one using the ordinary means of discovering legal precedent-indices and digests-would encounter very little beyond bare generalizations and in a large number of instances nothing. The period is 1934 to date. Treatises: 2 Beale, A Treatise on the Conflict of Laws (1935). Only pages 1245-1250, in a three volume work, are devoted to this subject. Falconbridge, Essays on the Conflict of Laws (I947) contains nothing; DICEY, Conflict of LAws (6th ed., Morris, 1949) disposes of the subject in 5 pages; 2 Rabel, The Conflict of Laws-A Comparative Survey (1945), contains only 2 pages-376-378. Casebooks have also given the matter a very summary treatment: BEALE, CASES ON THE CoNfLICT OF LAws (de Sloovere ed. r94I) contains one case-Gilbert v. Bernstein. LoREnzen, Cases and Materials on the CoNfLICT of LAws (5th ed. I946) gives the subject its fullest casebook treatment-an entire chapter of less than 20 pages. In the sixth edition by Stumberg (195I), this chapter is unchanged. ChEathas, Goodrich, Griswold, and Reese, Cases and Materials on the Conflict of laws (3d ed. 195i), contains a fair treatment of the matter in one chapter of 15 pages. Harper, Taintor, Carnahan and Brown, Cases and Materials on the Conflict of Laws (1950) dismisses the subject with a footnote and 6 pages of text. The Restatement of the Conflict of LAws, including the I948 Supplement thereto, makes no direct mention of the subject. It deals indirectly with the matter in Sections 81 and 90 , 
The general purpose of the conflict of laws (although it has been variously stated by various persons $)^{4}$ is to achieve substantial uniformity of result in deciding a legal problem regardless of the accident of the place of litigation. Or, if uniformity has not been its main end, then at least a reasonable satisfaction of the legal expectations of the parties has been its declared purpose. In the field of commercial arbitration, it seems that the conflict of laws has been of disservice-has had a destructive rather than a constructive effect on the development of commercial arbitration.

It should be stated at the outset that this article is written with a number of predispositions, not prejudices but feelings. The first is that commercial arbitration is "a good thing," and that, as a good thing, no substantive or regulatory field of law ought to hinder its development. The second is that the conflict of laws, if it is to fulfil its proper role, ought to have as its main purpose the achievement of a substantial similarity of results regardless of the accident of the place of litigation.

As the field of inquiry has been limited, ${ }^{5}$ the conflict of laws has been responsible for three principal disservices to commercial arbitration. The first has to do with the characterization problem. In the application of the conflict-of-laws characterization principles, a proper distinction has not been made between the contract in general and the arbitration clause in that contract. ${ }^{.}$A failure to apply the proper

and in the 1948 Supplement, Comment D to Section 2 and a note to Section 584 treat a collateral point of importance (see note 7 infra). The Annotated Reports, Digests, Encyclopedias, and Indices to Legal Periodical Literature, while containing some material on arbitration and award and some on the conflict of laws, disclose little, if anything, of value dealing with a juxtaposition or interplay between the two fields. It is regrettable to note that this statement applies with equal validity to the specialized journal dealing wih arbitration matters, The Arbitration Journal, and its New Series, although it must be admitted that the coverage of the other problems affecting commercial arbitration is excellent. The Annual Surtey of American Law contains one of the best coverages of the conflict of laws and commercial arbitration: Derenberg, r942 Annual Surv. Am. L. 896; 1943 id. at 830; 1944 id. at II41; 1945 id. at I220; 1946 id. at II82; Teller, I947 id. at 1084 (there is excellent treatment even though the title was changed from Commercial Arbitration to Arbitration in order to include cases arising out of labor-management disputes); $1948 \mathrm{id}$. at $90 \mathrm{r}$; $1949 \mathrm{id}$. at $999 ; 1950 \mathrm{id}$. at 832. It is unfortunate that the editors of the Survey, recognizing the importance of this field as they do, have continued to include it under the heading Adjective Law, thus perpetuating the classification originally made by Judge Cardozo.

As to the calculated confusion, this is represented by the few legal opinions in the last two decades dealing with the particular subject matter; since they will be discussed at greater length in the article to follow, it may be dismissed at this time with the general characterization already given.

The forthcoming new edition of Sturges, Commercial Arbitrations and Awards should go a long way toward remedying both of these matters.

- For a general review, see I Rabel, Conflict of Laws-A Comparative Study (1945); Cook, The Logical and Legal Bases of the Conflict of Laws, 33 YALE L. J. 457 (1924); Lorenzen, Story's Commentaries on the Conflict of Lasus-One Hundred Years After, 48 Harv. L. Rev. 15 (1934).

'No attempt will be made to deal with the conflict-of-laws problems involved in international commercial arbitration. The problems of labor arbitration are also beyond the proper scope of this discussion. In view of the other papers being submitted in this symposium, there are enough problems containcd within the national scene to be dealt with in a paper of this length.

${ }^{\circ}$ The jurisdictions in the United States can be divided into three categories in so far as rules affecting arbitration are concerned. In all but two of them some form of arbitration is valid. The overwhelming majority admit common law arbitration and the submission of an existing dispute either with or without a ruling of court. Except in so far as it becomes material to the discussion of the public policy in these jurisdictions, it will be assumed that an arbitration necessitates the express presence of the partics and consent to the exercise of the jurisdiction of the courts. Where that is present, no rcal difficulty in the enforcement of a judgment entered on such award can arise-that is, no real difficulty for the conflict of laws. Therefore, throughout this paper arbitration clause will be used to mean an agrecment to submit disputes, the validity of which is questioned under a statute making such agrecments irrevocable and specifically enforceable. 
rules of characterization can have a very serious effect on the solution reached in the particular case.

The second disservice which the conflict of laws has rendered to commercial arbitration is in the failure to develop a proper set of rules applicable to the enforcement of foreign judgments based on arbitral awards. And finally, while this cannot be laid completely at the doorstep of the conflict of laws, there is the failure to develop complete and adequate due process concepts in the field of commercial arbitration. ${ }^{7}$

\section{Characterization and the Arbitration Clause: Substance or Procedure?}

Normally when the courts have been faced with the problem of deciding what should be the proper law applicable to a contract containing an arbitration clause, they have gone through a syllogism something like the following: Arbitration is remedial. That which is remedial is procedural. That which is procedural, in the ordinary sense, is procedural in the conflict-of-laws sense. That which is procedural in the conflict-of-laws sense is governed by the lex fori. ${ }^{8}$ There are many fallacies involved in this process of reasoning, but the most grievous of them is that the result which is achieved is very often the exact negation of the pronounced intent of the parties to the agreement. Modern commercial arbitration is purely consensual in nature. Therefore, it must be assumed that the intention of the parties is always applicable to the agreement which may give rise to the arbitration. There is no doubt, and the Supreme Court has supported this view, that there are limits to choice of law. There are limits on the forum and there are limits on the parties. ${ }^{9}$ The general rule, for example, that the parties cannot grant exclusive jurisdiction to the courts of any one place, is still followed. ${ }^{10}$

\footnotetext{
'As to both the points noted above, the second and third disservices indicate that both the enforcement of foreign judgments and the due process regulation are passing into the field of constitutional regulation. The clarification presented in Goodrich's discussion of Guaranty Trust Co. v. New York, in RESTATEMENT OF THE LAW (1948 Supp.) is invaluable. While conflicts substance-and-procedure and constitutional substance-and-procedure must be distinguished terminologically, the former is still the father, even if possibly illegitimate, of the latter, and the basic thought patterns underlying the former cannot be lost sight of.

${ }^{8}$ Lorenzen, supra note I, at $49 \mathrm{I}$ : "One thing stands out above all else, namely, that from the standpoint of the conflict of laws the attitude of the United States toward commercial arbitration is not shared by any other country, not even Great Britain. The dominant point of view in our law is that agreements for arbitration relate to procedure or remedy."

${ }^{\circ}$ Cf. a long line of authorities from Home Insurance Co. v. Dick, 28r U. S. 397 (I930) through Hartford Accident \& Indemnity Co. v. Delta and Pine Land Co., 292 U. S. I43 (I933) to Hughes v. Fetter, 34I U. S. 609 (I95I).

${ }_{10}$ This is certainly true where there is no contact with the law selected. Lorenzen, supra note $\mathrm{I}$, at 470 n. 88, and authorities cited therein. See generally excellent discussions, Choice of Law by Contractual Stipulation, I6 U. of CHI. L. REv. I57 (1948), and Comment, Agreements in Advance Conferring Exclusive Jurisdiction on Foreign Courts, Io LA. L. Rev. 293 (I950). That it may still be true where there is a contact, see Parker v. Krauss Co., Ltd., 157 Misc. 667, 284 N. Y. Supp. 478 (Sup. Ct. I935), Note, 20 Cornel. L. Q. 369 (1935), and a recent decision cited by Goodrich in his excellent survey, Eleven Years of Two-State Law, 3 SYRAcuse L. Rev. I, I7 (I95I), Rhodes \& Co. v. Chausovsky, 137 N. J. L. 459, 60 A.2d 623 (Sup. Ct. 1948). In this case, the Supreme Court of New Jersey refused to decline jurisdiction in a dispute involving a contract executed in New York by an Illinois corporation (authorized to do business in New Jersey) and by two residents of Argentina, notwithstanding the fact that the parties had stipulated for Argentine law to govern and that there was a provision for the arbitration in Buenos Aires of disputes arising out of the agreement.
} 
It is apparent that the operation of classification procedures in the field of arbitration clauses by the ordinary court is not being done in a field of law where public policy is a dominant element. The usual court, and many instances could be cited of this, still will go through a process of logical progression something like that stated at the outset of this section. Because there is something remedial about the arbitration proceedings themselves, must its remedial phase characterize the whole lawselecting operation ?11

This part of the judicial operation might be attributed to a historical accident; the fact that when the first modern arbitration statute was passed in the United States-the New York Act of I920-it was placed in the Civil Practice Act for lack of any better place to put it. Parties to an agreement include an arbitration clause and select a law which they assume will give effect to the entire agreement. They are not thinking in terms of substantive parts of the contract, formal parts of the contract, and most certainly they will not be thinking in terms of the conflict-of-laws split between substance and procedure. These people are usually dealing with an entirety, establishing a framework which will govern continuing legal relations. If they are in such a mood, it seems only realistic to further rather than frustrate such a purpose. It must be stated that there are many jurisdictions in the United States that do not share the predisposition of this writer that arbitration is "a good thing."12 The many jurisdictions that have never adopted a modern arbitration statute present a negative type of problem. Simply stated, it is this. A party in such a jurisdiction enters into an agreement having a clause for the arbitration of disputes. This clause grants jurisdiction to a state which has a modern act. In spite of this selection of law by that party can his state, or another, as forum, apply its own policy and strike down the agreement of the parties? If it is not the present rule, it is submitted that the answer ought to be no. Where the parties have expressly chosen a law or where the contacts are so obvious as to make one jurisdiction the center of gravity (the proper law in the English sense of the word), that law, in its entirety, ought to be applicable. "In its entirety" does not mean including phases of the chosen law that would override purely procedural elements at the forum. The amount of law of a place chosen falling within the scope of "contract" will be something variable, but acceptance of the validity of a choice of law by the parties will end merely mechanical non-enforcement of arbitration agreements. The fact that the legislature of a particular jurisdiction has never passed a modern act indicates

${ }^{11}$ Lorenzen, supra note 1 , at 472 : "Will the courts go so far in their procedural point of vicw as to hold that the law of the forum governs without regard to the law of the state where the contract is made or the arbitration is to take place? The modern legislation making arbitration agreements enforceable has been held to be remedial for some purposes; will it be held to be remedial for all purposes? Suppose a contract was unenforceable both by the law of the state where it was made and the law of the state where the arbitration is to be held, would it be enforceable nevertheless in any state having a modern arbitration statute? No direct decision on the point has been found." Still no direct decision on point has been made!

${ }^{12}$ A summary of this learning boldly stated by a very learned writer who does not share my predisposition is to be found in Phillips, A Lawyer's Approach to Commercial Arbitration, 44 YALE L. J. 3I (r934), and see also Synthetic Courts-A General Introduction, 83 U. of PA. L. REv. II9 (1934). 
a lack of interest rather than a positive aversion to modern commercial arbitration such as would properly found a refusal based on contrary public policy. Any country where more than a third of the jurisdictions (and within that third those commercially more significant) have adopted a uniform act cannot be said to be opposed to the notion of commercial arbitration. The element of public policy cannot be viewed in a vacuum. Progress will be possible in this field if the courts will solve conflict-of-laws problems in the light of a realistic evaluation of the elements rather than a consideration along purely classical lines.

As typical of the many decisions which follow the logical progression first outlined in the beginning of this section, consider the case of Gantt v. Felipe $y$. Carlos Hurtado \& Cia., Ltda.13 This decision involved an agreement made in North Carolina between a Nicaraguan corporation and a seller of finished lumber products which called for arbitration in New York under the laws of New York. When the case came to be litigated, Gantt maintained that the selection of the New York law was impossible, or, at best, invalid. Because North Carolina does not have a statute incorporating a modern arbitral procedure, the New York Court of Appeals, in its opinion, considered this argument and dismissed it. No one will quarrel with the result; it was probably eminently sound. But the reasoning that supports the result showed that the Court of Appeals was thinking along the traditional lines. The court said, in effect, this litigation makes New York the forum. ${ }^{14}$ Arbitration is something essentially procedural. It is a means other than the judicial means for the settlement of disputes. ${ }^{15}$ Therefore, since it is procedural, we will classify it as procedural in the conflict of laws sense; being procedural in that sense, it is governed by the law of forum. The forum happens to be New York. New York has a modern act, an act which is eminently in favor of arbitration. New York, in other words, considered arbitration a good thing. Therefore, the result is a very simple one.

Consider the basis of this case. The parties contracting in North Carolina have decided to govern either the entire agreement or at least the arbitration clause in that agreement by the laws of New York. Was there any necessity for the New York court to validate this particular arrangement on the basis of characterizing the clause as procedural and as governed by the laws of forum? Would it not have

${ }^{13} 297$ N. Y. 433,79 N.E.2d 815 (1948).

14 The rule has long been that a proper arbitration clause goes further and represents a consent to the jurisdiction of the New York courts. Bradford Woolen Corp. v. Freedman, I89 Misc. 242, 7I N.Y.S.2d 257 (Sup. Ct. 1947); Merger Fabrics, Inc. v. Coill-Shuman, 74 N.Y.S.2d 76 (Sup. Ct. 1947); Prosperity v. American Laundry Machine Co., 27 I App. Div. 622, 67 N.Y.S.2d 669 (4th Dep't I947), leave to appeal denied, 297 N. Y. 486, 74 N.E.2d I88 (1947). The clause must refer to the rules of an association providing for consent or grant jurisdiction to the courts of the state or provide for arbitration under the laws of New York. But that this rule will be narrowly construed, see Jackson v. Kentucky River Mills, 65 F. Supp. 60x, 603 (E. D. Ky. 1946), where a general provision for arbitration in New York and enforcement by any court "having jurisdiction" was construed to require one of the traditional bases of jurisdiction. For other cases, see Restatexent, Conflict of Laws $\$ \$ 77$, 8I, and go (1934) and annotations to these sections in Restatement IN tHe Courts (Perm. Ed. 1948).

${ }_{15}$ For a criticism of the foundation case, see Lorenzen, supra note $I$, at 469 . 
been sounder to say: Let us look to the law of North Carolina. That is the place where the agreement was made. Now, according to the law of North Carolina, its own internal law, if applicable under the-place-of-making doctrine, would not permit an arbitration agreement calling for arbitration in North Carolina. But, there is no reason for the New York court to presume that the choice-of-law rules of North Carolina would not permit the parties to select, in an agreement made in North Carolina, the law of another place to govern any particular element of the contract. The defendant's argument that the absence of a modern statute, or even a statute permitting arbitration by rule of court, embodies an affirmative public policy depriving the parties of the capacity to contract with the law of another place in view is specious. Now, the New York court has saddled the inferior courts of that state with a continuance of the well accepted rule ${ }^{16}$ that arbitration is procedural. In a future case an agreement made in New York calling for arbitration in Illinois may be litigated in Florida, and let us suppose that Florida like North Carolina does not permit enforcement of arbitration agreements. Florida will then characterize the clause as procedural; being procedural, it will be governed by the law of forum; being governed by the law of forum, the arbitration agreement will be invalid.

Enforcement of the Arbitration Process: Extraterritoriatity, Local Law, and Public Policy

At one time it was assumed that an arbitration agreement acted as an ouster of the jurisdiction of the courts. ${ }^{17}$ The common law courts have always guarded their jurisdiction zealously. Present day apologists for the doctrine assume that the statutory changes of this country are insignificant. ${ }^{18}$ Why should we continue a

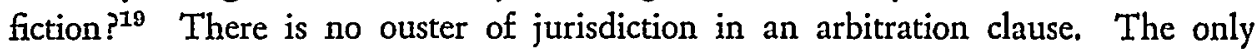
possible way that a party can be compelled to comply with an award under an arbitration agreement will be if some means of enforcing it against him are available. In all of the modern acts, adequate safeguards are granted all of the parties. In the conflict of laws, more particularly, an award can have no extra- territorial effect unless it has been sanctioned by the governmental unit issuing $\mathrm{it}^{20}$

\footnotetext{
${ }^{10}$ Stemming from the Matter of Berkovitz v. Arbib \& Houlberg, 230 N. Y. 26r, I30 N. E. 288 (I92I).

${ }_{17}$ The fallacy of this position is exposed by Lorenzen, supra note 1 , at 456-457; for further historical background, see Cohn, Commercial Arbitration and Rules of Law: A Comparative Study, 4 U. of Toronto L. J. I (1941).

${ }^{18}$ For the effect that the enactment of a modern act might have on a typical United States jurisdiction, see Katz, Enforcement in Ohio of Contracts to Arbitrate in Another State, 9 U. or CiN. L. Rev. 273 (1935).

${ }^{10}$ That it is only this, see summary in majority opinion in Park Construction Co. v. Independent School District No. 32, 209 Minn. 182, 296 N. W. 475 (1941), 8 U. of CHI. L. Rev. 756, 758 n. 17 (194I); see Note, 135 A. L. R. 59 (I94I), where at page 9I this interesting statement appears: " $A s$ it now stands, the case law in regard to the validity of general arbitration clauses is confused in statement and theory, poorly reasoned, arbitrary, and not well designed to accomplish a useful purpose."

${ }^{20}$ The effectiveness of the jurisdictional attack to limit full faith and credit to a judgment entered on an award is undoubted. If the judgment can be set aside and award vacated at the granting court, no greater credit need be extended. See Popkin and Jacobinson, Jurisdiction Over the Non-Resident in Arbitration Proceedings, I7 N. Y. U. L. Q. REv. 527, 528 n. 4 (1940).
} 
A mere private order out of a private group of persons associated to hear disputes would not be enforced. This is not the same as saying that the enforceability of an award is conditioned on its reduction to judgment. But certainly something comparable to that result-that is, the reduction to judgment-must be accomplished or no effect whatsoever can be given an award. It is clear from a study of the judge-made law that the characterization process is not too well or too completely understood, and yet no assistance has come from practitioners or "the experts." The last generation and a half has acquiesced in this misuse of the characterization process. Part of the confusion stems from a failure to distinguish between enforcement of the contract and enforcement of the award, because adequate attention has not been given the jurisdiction factor. Technically, jurisdiction is not a part of the conflict of laws. Practically, since it underlies the enforceability of any judicial proceeding, it has always been considered a part thereof. The jurisdictional problems that can arise in the field of commercial arbitration are many. ${ }^{21}$

Normally, for the common law court personal jurisdiction must be had over the particular party. If the party is a juridical person, qualified to do business in the state, there really is no trouble at all. If the party is an individual, several questions may arise. First, can the party submit himself to the jurisdiction of another courtthat is, being in North Carolina can he validly submit himself to the jurisdiction of the courts of New York? There are two aspects to this, both of which were considered in the Gantt case. ${ }^{22}$ One, the problem of the surrender of jurisdiction, and the second, that of the exercise of jurisdiction. Then there are the problems of controlling the conduct of a party beyond the jurisdiction of the court before which he happens to be present. ${ }^{23}$ There are also problems of extraterritorial assistance in

21 See Lorenzen, stupra note $x$, at 497 .

22297 N. Y. 433 , 79 N.E.2d 815 (1948).

${ }^{23}$ Cf. P. Beiersdorf \& Co., Inc., v. Duke Laboratories, Inc., 94 N.Y.S.2d 18 (Sup. Ct. r949) (holding that the underlying contract was valid and represented a consent to the jurisdiction of the court), aff'd, 277 App. Div. 768, 97 N.Y.S.2d 538 (xst Dep't 1950), aff'd, 30r N. Y. 705, 95 N.E.2d 55 (1950). This recent and rather complex litigation discloses the many problems involved herein. Out of this basic decision came two collateral proceedings. One in the federal courts concerned a matter specifically excepted from the arbitration agreement. P. Beiersdorf v. Duke Laboratories, Inc., 92 F. Supp. 287 (S. D. N. Y. 1950). Defendant here, who was the plaintiff in the other collateral proceeding in the Connecticut state courts, moved for a stay of these proceedings or alternatively for a transfer of the state action to the district court in Connecticut. The transfer was denied but the stay was granted in accordance with the policy against multiplicity suits based on Mottolese v. Kaufman, 176 F.2d $30 \mathrm{r}$ (2d Cir. 195I). Beiersdorf then filed a petition for leave to file a petition for a writ of mandamus. The Court of Appeals ( 187 F.2d I4 (2d Cir. 195I)) held that the court could entertain the petition but decided against petitioner on the merits. The importance of the extra-arbitral means of assisting that procedure is shown in the following language from the court. For the majority (Frank and Chase, JJ.): "Judge Chase and I think that we must decide against petitioner on the merits because of this court's recent decision in Mottolese v. Kaufman, I76 F.2d 301 (2d Cir. I95I).

"Judge Chase regards Mottolese as correctly decided. I dissented in that case, and still consider the decision wrong for reasons stated in detail in that dissent. Were I to join Judge Clark in the instant case, victory here would go to petitioner. But I believe that the considered rationale of the majority opinion in Mottolese was so sweeping that it should not be avoided merely on the basis of the different facts here. I feel, therefore, that I must be content with hoping that the Supreme Court, recognizing an 'intra-Circuit conflict' [footnote of the court omitted], will grant review and reverse this decision, which involves an important problem of federal jurisdiction."

For the minority (Clark, J.): "There may be grave doubt, under the Connecticut counterclaim pro- 
making effective the arbitral procedure. There are the problems of the control of the scope of the arbitration proceeding within the particular jurisdiction through the underlying agreement. ${ }^{24}$

The most difficult question that arises in the general problem of jurisdiction, if one removes the question of the capacity of the parties to enter into an agreement, is the following. Presuming capacity to enter the agreement because the public policy objections would not be too strong, $A$ in North Carolina enters into an agreement with $B$ in New York to settle all differences by arbitration under the laws of New York and in accordance with the rules of the American Arbitration Associa-

vision which is narrower than the federal one, Clark, Code Pleading 12r, 643, 647, 2d Ed. 1947, whether the petitioner here can get in the state action all the relief to which it is entitled; perhaps that explains the retention of some jurisdiction below with power to cither party to "apply for further relief at the foot of this order.' Part or all of the Connecticut proceedings may come to nothing anyhow, for in yet another action ${ }^{2}$ the New York Court of Appeals, 301 N. Y. 707, 95 N.E.2d 55, has affirmed a holding that the contract here in dispute must first go to arbitration."

1 There appears to be still another action pending in the federal court in Connecticut against petitioner's officers apparently raising some of these issues; one wonders, indeed, why, amid this wciter, the action below is the one chosen to be stayed."

In the main other collateral proceeding, the order of Judge Hecht at the Supreme Court was refused full faith and credit (Superior Court, Fairfield County, No. 79840, April 5, 1950, unreported) when asserted by defendant as grounds for a stay. Although the case was admirably bricfed for Bciersdorf on appeal to the Supreme Court of Errors of Connecticut, the whole litigation was settled before a decision by that court. Therefore, this extremely important point of whether a stay of procecding pending arbitration will operate extraterritorially has been left undecided not only in the state courts but in the federal courts as well, the former expressly and the latter tacitly. Cf. Cerro de Pasco Copper Corp. v. Knut Knutsen, O.A.S., I87 F.2d 990, 991 (2d Cir. 195x). On the question of a state compelling arbitration beyond its territory and the availability of provisional remedies, sec American Reserve Insurance Co. v. China Insurance Co., Ltd., 297 N. Y. 322, 79 N.E.2d 425 (1948); and Note, 24 N. Y. U. L. Q. REv. 224 (I949).

24 Problems that arise here are: What law shall be chosen to define the scope of the meaning of the term "arbitral issue"; "separability" of the arbitration clause from an invalid main contract; and the Statute of Frauds. In the matter of the scope of the arbitrators' powers, a leading case is Petition of Pahlberg, 43 F. Supp. 76r (S. D. N. Y. 1942), appeal dismissed, 131 F.2d 968 (2d Cir. 1942), in which A. Hand, $J$., stated that all issues are subject to the arbitration clause cxcepting only the questions of whether the contract was ever made or was void for fraud or illegality, citing and following the rule of the House of Lords in Heyman v. Darwins, [1942] A.C. 356 . As to the construction of the point whether there is any distinction between the terms, differences arising "under the contract" or "during the contract," see Stathatos v. Arnold Bernstein Stcamship Corp., 87 F. Supp. 1007 (S. D. N. X. 1950). Further comments are to be found in the article by Sturges and Ives, infra note 41 , at 756 .

On the question of the separability of the arbitration clause from an otherwise invalid contract, sce Nussbaum, The "Separability Doctrine" in American and Foreign Arbitration, I7 N. Y. U. L. Q. Rev. 609 (1940); id. at 672, noting Metro Plan, Inc. v. Miscione, 257 App. Div. 652, 15 N.Y.S.2d 35 (Ist Dep't 1939). The direct authority for the separability doctrine in New York is Marchant v. McadMorrison Mfg. Co., 252 N. Y. 284, 169 N. E. 386 (1929); Note, I6 N. Y. U. L. Q. Rev. 604 (1939). See also Nussbaum, Conflict Theories of Contracts: Cases Versus Restatcment, 5 I YALE L. J. 893 (1942), especially $9 \mathrm{II}-9 \mathrm{I2} \mathrm{n}$. II6. This article incidentally represents one of the major contributions made to the learning in this field in the period from Lorenzen's article to date and discusses very capably all of the problems arising in the contract field.

As to the problem of the Statute of Frauds, see Note, I6 N. Y. U. L. Q. REv. 604, 610 (1939), and Albert v. Goor, 70 Ariz. 214, 218 P.2d 736 (1950), contra, holding that where the arbitration stemmed from a parole agreement to sell real estate invalid under the Statute of Frauds, the invalidity of the basic agreement made the arbitration agreement invalid. But see discussion in Teller, I950 ANwuL SuRv. AM. L. 833. No attempt is made herein to discuss the contracts choice-of-law problem discussed by Nussbaum in the article cited above, since few, if any, of the courts have separated consideration of a contract containing an arbitration clause from one without such a cause. The modern law would indicate that the defects in the contracts field will have to be cured as a separate matter. 
tion (or any organization having similar rules). One of the provisions in the rules is that personal jurisdiction is acquired over $A$ by the service of notice at his address by registered mail. A dispute arises. $B$ carries out an essentially $e x$ parte proceeding complying, however, with all the notice requirements contained in the rules. An award is made and judgment entered thereon. When enforcement of that judgment is sought outside of New York, can $A$ attack the enforcement on the grounds that if granted it would violate the due process clause? Or, as has more frequently happened, will the judgment survive an attack made by $A$ under the full faith and credit clause? Recent decisions ${ }^{25}$ indicate a healthy respect for the newly reinvigorated full faith and credit clause. Unless there is a stronger policy where enforcement is sought than usually exists, the proceedings will be held valid against both types of attack.

One must understand that it is not a court's jurisdiction that is really being extended. Since the effect of an arbitral proceeding is similar once the force of the state is behind it, this is a strong indication of the substantive nature of an arbitral proceeding. If this were procedural in the sense and as the whole thing is sometimes classed, then how can one court recognize the granting of jurisdiction to litigate a problem to another tribunal? It must, of necessity, be classified even though still remedial as a substantive matter in the conflict of laws. This, of course, has long been the rule in those states which have modern arbitration acts. ${ }^{26}$

${ }^{25}$ See generally Moyer v. Van-Dye-Way Corp., I26 F.2d 339 (3d Cir. I942); Mulcahy v. Whitehill, 48 F. Supp. 917 (D. Mass. 1943) (judgment based on registered mail service under American Arbitration Association rules, held entitled to full faith and credit); followed in Ripley Fabrics Corp. v. Hymen, 9I F. Supp. I007 (N. D. Ill. 1950) (same result reached under the rules of the National Federation of Textile Manufacturers); see excellent discussion of this case in 29 CorNell L. Q. 526, 529 (1944). The result in the Ripley case was followed by the Illinois court in Tanbro Fabrics Corp. v. Hymen, $34 \mathrm{I}$ Ill. App. 396, 94 N.E.2d 93 (I950), involving an arbitration under the rules of the same association. The result in the last two cases is based in part on Marvlo Fabrics, Inc. v. Jarus, 87 F. Supp. 245 (W. D. Mo. 1949), and is followed in New York where substituted service is valid under Section 1450 of the N. Y. C. P. A. Application of Liberty Country Wear, Inc., I97 Misc. 58r, 96 N. Y. S.2d I34 (Sup. Ct. I950).

${ }^{20}$ Lorenzen, supra note $\mathrm{I}$, at 4 68-469: "The following situations involving a foreign element may present themselves, whether or not the state be one having a modern arbitration act: The contract may be made in the state and call for arbitration in another state or in a foreign country, or it may be silent on the question where the arbitration is to take place. Or the contract may have been made in some other state or country without specifying where the arbitration is to take place; or it may call for arbitration in the state of the forum, or it may call for arbitration in a third state. Finally, it may not appear where the contract was made, but the place of arbitration may be specified to be the state of the forum, or some third state or country.

"In each of the above situations, the law of the state in which the contract was made may render it irrevocable or revocable and unenforceable. If it is valid and enforceable by the lex loci, it may be unenforceable by the law of the state or country in which the arbitration is to take place; or, what is more likely to happen in fact, it is made in a state or country under the local law of which it is unenforceable, and arbitration is to take place in a state or country in which it is valid and enforceable. Further complications will occur if the residence or domicil of the parties is a material factor, for in each of the above situations both parties may be residents of the same state or country $\longrightarrow$ of the state or country where the agreement for arbitration was made or where the arbitral tribunal is to sit, or of the forum, or of some other state or country-or they may be residents of different states or countries.

"Which of the above cases would fall within an arbitration statute of the forum? If it falls within such a statute of the forum for one purpose, does it necessarily fall within it for all purposes? Will a stay of proceedings be granted by virtue of the arbitration statute of the forum? Will the parties 


\section{Federal Arbitration}

Arbitration in the federal sense presents two entirely different aspects. The first is the question of whether there is, and, if there is not, whether there should be, a diversity jurisdiction. The second is the scope and utility of the present Federal Arbitration Act. As to the diversity jurisdiction of the federal courts, should there be a separate rule regarding arbitration? Wolkin, ${ }^{27}$ in a very competent survey of the Erie ${ }^{28}$ rule does not explicitly mention the possibility nor should he as he is dealing with the law as it is rather than as it should be, and this particular question has not been raised and settled in the courts. There is a clear overtone from his article that federal conformity has already been carried too far. Admittedly, the rule in Swift $v$. Tyson ${ }^{29}$ created a great deal of dissatisfaction, but why replace it with an equal tyranny? ${ }^{30}$ Since the courts have not dealt with this question, and it is clear that there are still advantages to litigation in the federal courts, how can the Erie doctrine be best interpreted? This country needs at least one place where uniformity is more than a ghost of a hope. Dean, ${ }^{31}$ speaking for the conflict of laws, has pointed up the special obligation of this field. There is a serious danger that under the present construction of the Erie doctrine, almost all of the truly procedural advantages will be limited and perhaps liquidated. ${ }^{32}$

In this strange, new procedural-substance split, where is the arbitration clause to be placed? Thus far only one Circuit Court of Appeals case-Tejas Development Co. v. McGough Bros. ${ }^{33}$-has mentioned the problem. ${ }^{34}$ This court made the law substantive and by referring it under that characterization to the law of Texas destroyed its efficacy. This characterization is probably correct in view

be ordered to proceed to arbitration in another state or country? Under what circumstances will an arbitrator be appointed in accordance with the local statute? The actual decisions of the courts in this country throw little light upon the problems suggested; so far as they point in any definite direction it would appear that they are unfavorable from the standpoint of interstate and international commerciall arbitration."

This is one of the many instances referred to in note $r$, supra, where Lorenzen placed his fingers on the heart of a problem. The discussion above shows that the decisions probably reflect a change in direction from one unfavorable to one favorable. The paucity of them indicates, howcver, that very little steam has been gotten up in the courts to proceed vigorously in a favorable direction.

${ }^{27}$ Conflict of Laws in the Federal Courts: ${ }_{3} 3$ Years of Erie R. Co. v. Tompkins, 3 SYracuse L. Rev. 47 (I95I).

${ }^{28} 304$ U. S. 64 (1938). $\quad{ }^{20} 16$ Pct. I (U. S. I842).

${ }^{30}$ For an early article taking this position, see Broh-Kahn, Uniformity Rttn Riot-Extensions of the Erie Case, 3r Ky. L. J. 99 (1943).

31 The Conflict of the Conflict of Laws, 3 Stan. L. Rev. 388 (195I).

32 This danger is stated very clearly in a note, The Erie Case and the Federal Rules-A Prediction, 39 GEo. L. J. 600, 6ro-6rI (r95I). The writer of that note takes the position that the Supreme Court has indicated in the Cohen case (Cohen v. Bencficial Loan Corp., 337 U. S. 54I (1949)), that it will call a halt to the destruction of the Federal Rules by protecting Rule $23(\mathrm{~b})$. The validity-and it is hoped that the writer is correct-of this prediction may very soon be tested because Judge McGohey in a recent decision in Fuller v. American Machine and Foundry Co., 96 F. Supp. 606 (S. D. N. Y. 195I) has ruled that 23 (b) must yield in a diversity situation to the New York state law. See Note, 39 GEo. I. J. 600,609 (195r).

${ }^{33}$ I65 F.2d 276 (5th Cir. 1947). The best reasoned opinion contra classifying arbitration as procedural in the diversity jurisdiction is contained in Pioneer Trust \& Savings Bank v. Screw Machine Products Co., 73 F. Supp. 578 (E. D. Wis. 1947).

${ }^{34} 165$ F.2d at 279. 
of the "substantial effect" doctrine of Guaranty Trust Co. v. York. ${ }^{35}$ Whether it is the correct interpretation of the substantive law of the state of Texas, including its conflict-of-laws rules, is another problem. Certainly, if the law of that jurisdiction allows the intent of the parties to control selection of the governing law, these parties by referring to arbitration under the rules of the American Institute of Architects inferentially made their intention run to the law of a place where that agreement would be given effect.

The Federal Arbitration Act ${ }^{36}$ itself presents some hope. Unfortunately most of the courts ${ }^{37}$ have denied completely the power of the parties to select the arbitration provisions of this Act as a matter of contract. Section 2 appears to limit jurisdiction to matters arising in maritime and interstate commerce, ${ }^{38}$ and there is no question that an adoption of the proposed amendment of the $\mathrm{Act}^{39}$ or some other statutory reformation will be necessary to include within the scope of the Act all matters cognizable by the federal courts. The lapse of time would indicate that the Supreme Court should strain every effort to liberalize and broaden the utility of the Act meanwhile. This can be done most effectively by enlarging the provisions contained in Section 3 for the granting of a stay pending arbitration, and those in Section 4 for the compulsion of arbitration. At the present time, the third circuit ${ }^{40}$ leads a group of circuits favoring a liberal interpretation of these provisions. Arbitration has been compelled in several instances beyond the territorial jurisdiction of the particular federal court ${ }^{41}$ and in one case, ${ }^{42}$ even beyond the territory of the United States. Stays pending arbitration have also been granted liberally. ${ }^{43}$

${ }^{35} 326$ U. S. 99 (1945).

3043 STAT. 883 , 9 U. S. C. \$1 (1925); enacted into positive law by Act, July 30, 1947, c. 392, 6I SтAт. 670, without changing any of its provisions, and designated officially as Title 9 , U. S. C.

${ }_{37}$ Jackson v. Kentucky River Mills, 65 F. Supp. 601 (E. D. Ky. 1946) is a decision in the right direction on this point, holding that within the scope of Section 2 (maritime commerce) the United States Act rather than the law of Kentucky is applicable. Id. at 603 .

${ }^{38}$ Most of the decisions have tended to interpret the interstate commerce provisions very narrowly. San Carlo Opera Co. v. Conley, 72 F. Supp. 825 (S. D. N. Y. 1946), aff'd, 163 F.2d 310 (2d Cir. 1947), noted in 28 NeB. L. Burl. 608 (1949). See Comment, Jurisdiction of the Federal Courts Under the U. S. Arbitration Act, 27 Texas L. Rev. 218 (1948). But cf. Shanferoke Coal \& Supply Corp. v. Westchester Supply Corp., 293 U. S. 449 (1935), noted in 48 Harv. L. Rev. I2I (1934).

${ }^{30}$ See discussion, Sturges, Proposed Amendment of the United States Arbitration Act, 6 ARB. J. 227 (1942), and Derenberg (1943), Annual Surv. Am. L. 837-840. Up to this time, none of the suggested changes or amendments have been adopted, although subsequent judicial interpretation has achieved in a limited fashion certain of the suggestions made in S. 2350 .

«n Donahue v. Susquehanna Collieries Co., I60 F.2d 66I (3d Cir. I947); Jones v. Mississippi Valley Barge Line Co., 98 F. Supp. 787,788 (W. D. Pa. 1951), reviewing the current state of this split in circuits, and following rule of its circuit; semble, Albatross v. Manning, 95 F. Supp. 459 (S. D. N. Y. I95I).

${ }^{41}$ Following the liberal Pennsylvania rule laid down in Nippon Ki-Ito Kaisha v. Ewing Thomas Corporation, 313 Pa. 442, 170 Atl. 286 (I934). An excellent discussion of the present status of this case is to be found in Sturges and Ives, Some Confusing Matters Relating to Arbitration in Pennsyluania, 99 U. of PA. Rev. 727, 757-759 (195I) and especially $758 \mathrm{n}$. 78. See generally authorities cited in Note, 17 N. Y. U. L. Q. REv. 644,650 (1940).

"Only by implication, however: Cerro de Pasco Copper Corporation v. Knut Knutsen, O.A.S., 187 F.2d 990 (2d Cir. I95I); cf. P. Beiersdorf v. McGohey, 187 F.2d I4 (2d Cir. 195I).

${ }^{13}$ Donahue v. Susquehanna Collieries Co., supra note 40 ; Agostino Bros. Building Corporation v. United States, I42 F.2d 854 (4th Cir. 1944). An excellent review is contained in Wilson \& Co. v. Fremont Cake and Meal Co., 77 F. Supp. 364 (D. Neb. r948). The later proceedings in this case give 
There is a lingering doubt as to the effectiveness of these judicial acts, however, because of the restrictive interpretation still maintained by other circuits. ${ }^{44}$ Congressional action being dubious, the obligation of the Supreme Court to resolve this conflict is even greater than it would normally be. As has been made obvious by well considered opinions, ${ }^{45}$ the attitude of mind of Congress in passing the origināl I925 Act and in re-enacting it in 1947 is one in favor of liberal enforcement of arbitration agreements. Why then should a decision furthering this purpose not be forthcoming from the Supreme Court? It is unfortunate that the short-circuiting process should have been done under guise of a conflict of laws rule, particularly such as took place in the Tejas case.

\section{ConcLusion}

What can be done in this field to rectify some of the errors and to lessen some of the disservices? The first thing that must be made very clear is that the possibility of the adoption by remaining jurisdictions of a uniform act concerning arbitration should not be overlooked. While the existence of such an act in all of our jurisdictions, as the experience with the Uniform Sales Act has shown, would not completely obliterate the conflict-of-laws problems, it would materially reduce their significance. What is most important is that the bar existing to the passage of such acts is apparently based on the same misconceptions that led to the confusion in this field. If the notion that an arbitration agreement is an ouster of jurisdiction of the courts can be disregarded, the conflict of laws would function in its normal way and the need for legislation would be lessened. Progress will not be made in this field until that idea is liquidated. The second idea that must be corrected is embodied in the fundamental error of Judge Cardozo that because arbitration is remedial (which is doubtful) it should be classified as procedural in the conflictof-laws sense. A contract with an arbitration clause and a contract without an arbi-

a clear insight into the complexity of the substance-procedure split inherent in this Act. See especially I 83 F.2d 57 (8th Cir. 1950) and 153 Neb. 160, 43 N.W.2d 657 (1950). The interplay between Sections 3 and 4 of the Act, the stay proceedings, and compulsion of arbitration is shown very clearly in a recent case, International Refugee Organization v. Republic S. S. Corporation, 93 F. Supp. 798 (D. Md. 1950). The case shows that, while technically not at issue, the granting of a stay may come very close to amounting to a compulsion of arbitration even though the specific powers of a federal court under the Federal Act to appoint arbitrators are not exercised. This case involved a charter party containing a clause calling for arbitration in London and stating that the intcrpretation of the agrcement was to be governed by the law of England. In granting a stay pending arbitration, the court said: ". . . the fact that the charter provides (par. 34) that it shall be interpreted according to the law of England is a further, logical reason for providing for arbitration in London. While the court cannot compel arbitration there or anywhere else, it can and should stay proceedings until it does take place." See also Modern Brokerage Corporation v. Massachusetts Bonding and Insurance Co., 54 F. Supp. 939 (S. D. N. Y. 1944); Uniao de Transportadores v. Companhia de Navegacao, 84 F. Supp. 582 (E. D. N. Y. I949).

"For a recent case typical of this point of view, see Lewittes \& Sons v. United Furniture Workers of America, 95 F. Supp. 85I (S. D. N. Y. 1951); contra in the same circuit, however, Albatross v. Manning, supra note 40 , relying to this extent on the opinion of Coleman, J., in Daniclsen v. Entre Rios Riys. Co., Ltd., 22 F.2d 326 (D. Md. 1927). See discussion in Lorenzen, supra note 1 , at 477-479, and comment by Teller, 1947 ANnuni, Sunv. Ax. L. 1085.

${ }^{25}$ For one of the most authoritative of these, sce Cook, The Federal Courts and the Conflict of Laws, 36 ILL. L. REv. 493, 506-507 (194I). See also the same author, Contracts and the Conflict of Latws, 32 ILL. L. REv. 899 (1938), especially the conclusion, id. at 919-920. 
tration clause are substantially different to the parties who have entered into that agreement. Provided the courts are given the opportunity in the proper way to regulate the arbitration process, to control the concentration of economic force, there should be no reason why the intention of the parties should be denied in this particular aspect. It is not a sufficient answer to the Cardozo characterization of arbitration as procedural to state that the proper law of contract will be looked to, to decide the essential validity thereof, and, upon finding the contract essentially valid, we then refer back to the law of the forum to determine the enforceability of the arbitration clause contained therein. If a law is to be chosen to determine the validity of the contract, that law ought also to determine the validity of the entire contract-the arbitration clause not excluded. Recent developments in the rule of Erie v. Tompkins show that the substance-procedure dichotomy is becoming a constitutional question, in fact, is more properly a constitutional than a conflicts question. If, therefore, what is substance and what is procedure has a constitutional importance to the federal courts sitting in diversity, the same decision will have constitutional implications if made by a state court.

The recent decision of the Supreme Court of the United States in Hughes v. Fetter ${ }^{40}$ makes it clear that "full faith and credit" limitations will be placed on the public policy of the various states. The implications of this case ought to be applied in the field of commercial arbitration. There are almost no states without some kind of an arbitration act and the basic validity of arbitration has not been questioned in the common law for almost three centuries. If the policy announced by the Supreme Court is applied, we should see extended the results reached in jurisdictions having modern arbitration acts. No state should be entitled to disregard the efficacy of such proceedings, when selected by the parties, on the basis of a statement that the result is against its policy.

In conclusion, therefore, the following steps ought to be taken by those persons interested in making the conflict of laws serve the cause of commercial arbitration: (I) a clear indication that the proper characterization of the process is as one of substance rather than procedure; (2) a strict adherence to the presumed policy implicit in the cases of Hughes $v$. Fetter with a consequent restriction on the public policy exception to the enforcement of both rights and judgments; and (3) the adoption of the changes suggested in the Federal Act and a constant and unrelenting policy of education leading to the adoption of a uniform act on the one hand and the careful control of the excesses on the other. With these various steps, it is felt that many of the obvious benefits of the arbitration process can be incorporated in and become useful to the common law system. Perhaps there are some lingering doubts about the need for a rejuvenation of that system of law. Too many impressive changes suggested in recent years to effect a more efficient administration of justice parallel the obvious advantages of the arbitration process to allow a blind rejection, through conflict-of-laws devices, of this very useful process.

${ }^{10} 34$ I U. S. 609 (I95I). 